\title{
Bacteria as a Murder Weapon: A Tale from Colonial Calcutta
}

\author{
Rudrajit Paul
}

\begin{abstract}
In this small article, the true crime story of a fratricidal incident in Calcutta during the 1930s has been recollected. The story is notable for the very unusual murder weapon used by the criminals. (Since this is a story about colonial times, the names of various Indian cities, as used in this article, reflect the names used during the British rule.)

Keywords: Bombay, Calcutta, Murder, Pakur, Plague.

Bengal Physician Journal (2019): 10.5005/jp-journals-10070-6112
\end{abstract}

\section{INTRODUCTION}

From time immemorial, human beings have killed each other for various reasons. Sometimes, it is for religious bigotry, sometimes for the lust of power or money and sometimes for love. Most murders are mundane affairs where the criminals are caught easily. For doctors, especially for those who perform autopsy, murders are usually straightforward cases with no mystery. But some murder incidents become famous either for the deviousness of the plot, or for the peculiarity of the murder weapon or for the uniqueness of motive. If medical persons are on the wrong side of law, then murder becomes an abuse of scientific knowledge. In this article, one such true murder mystery will be discussed. This murder case had a medical angle to it and doctors were on both sides: while some physicians were co-conspirators in the crime, the other physicians were instrumental in solving parts of the puzzle. It generated immense public interest in that era, not only in India but also abroad.

\section{The INCIDENT ${ }^{A}$}

Amarendra Chandra Pandey, a 20-year-old lad and one of the heirs to the Pakur Raj Estate, died on December 4, 1933 in Calcutta. The cause of death was later certified as bubonic plague.

Amarendra Pandey, along with his half-brother Benoyendra Chandra Pandey, was one of the joint heirs to the Pakur Raj Estate as well as the estate of their aunt, Rani Surja Bati Devi of Deoghar. Amarendra and Benoyendra, sons of the Raja of Pakur from different marriages, inherited the estates after death of their father, Kumar Pratapendra, in 1929. Pakur was a small but prosperous Zamindari Estate in Santhal Paragans of the present Jharkhand State. In fact, it was one of the richest estates of Bengal at that time (annual income approx. Rs.30,000, equivalent to about Rs.25,00,000 now). Thus, this inheritance involved a large property and prestige. However, at the time of his father's death, Amarendra was a minor. Thus, Benoyendra was the sole custodian of the estate and according to popular gossip and later, statements by his family members, he led a dissolute life, squandering the family riches. In 1931, Amarendra came of age and started to demand his share of the wealth. It was then that Benoyendra became his enemy. Benoyendra at first tried to coax and coerce Amarendra into subjugation. But Amarendra,
Department of Critical Care Medicine, Institute of Post Graduate Medical Education and Research and Seth Sukhlal Karnani Memorial Hospital, Kolkata, West Bengal, India

Corresponding Author: Rudrajit Paul, Department of Critical Care Medicine, Institute of Post Graduate Medical Education and Research and Seth Sukhlal Karnani Memorial Hospital, Kolkata, West Bengal, India, Phone: +91 9433824341, e-mail: r.paul.medicalcollege@gmail. com

How to cite this article: Paul R. Bacteria as a Murder Weapon: A Tale from Colonial Calcutta. Bengal Physician Journal 2019;6(2):37-39.

Source of support: Nil

Conflict of interest: None

with the help of his well-wishers and lawyers, tried to divide the estate and get his fair share. Then, Benoyendra decided to do away with his brother. ${ }^{1}$

This enmity would lead to one of the most innovative murder weapons in crime history.

On November 26, 1933, Amarendra was leaving Calcutta from Howrah station. As he was passing through the crowded platform, he brushed against an unidentified short man and immediately felt a prick in his right arm. ${ }^{2}$ The man was lost in the crowd and could not be traced. Amarendra showed the injury mark to the accompanying relatives and many of them were worried. They wanted him to immediately visit a doctor. But Benoyendra, who was also present to see the party off made light of the matter by saying that Pakur family members came from a line of warriors and did not retreat easily. Amarendra left for Pakur anyway but came back to Calcutta 3 days later with fever. He was attended by Dr Nalini Ranjan Sengupta at the Pakur Palace guesthouse in Calcutta. Dr Sengupta was then, one of the prominent physicians of Calcutta and it was he who found the mark of injection needle on Amarendra's arm and advised a blood culture. Dr Gupta from the school of tropical medicine was called to collect the blood sample. Amarendra became violently ill; his whole arm was swollen up, there was tachycardia and hypotension. Besides Dr Sengupta, he was also seen by some doctor brought by Benoyendra and this doctor misled the family members with false assurances about Amarendra's condition. On December 3rd, he

\footnotetext{
A Noted American journalist Dan Morrison recently came to Pakur to investigate this story. We may expect a more comprehensive monograph on this story in the future.
}

(-) The Author(s). 2019 Open Access This article is distributed under the terms of the Creative Commons Attribution 4.0International License (https://creativecommons. org/licenses/by-nc/4.0/), which permits unrestricted use, distribution, and non-commercial reproduction in any medium, provided you give appropriate credit to the original author(s) and the source, provide a link to the Creative Commons license, and indicate if changes were made. The Creative Commons Public Domain Dedication waiver (http://creativecommons.org/publicdomain/zero/1.0/) applies to the data made available in this article, unless otherwise stated. 
went into a coma and died 1 day later. One of the attending doctors refused to issue a death certificate but another doctor, probably at the behest of Benoyendra, issue the certificate promptly. The death was at first certified as "septic pneumonia" and the body was promptly cremated in the Kalighat Crematorium. ${ }^{3}$ The blood culture later grew the germs of bubonic plague at the school of tropical medicine. The matter was reported to the public health authority. There had been just one death from bubonic plague in Calcutta in the preceding 5 years and naturally this case roused interest in the medical community. Also, many renowned doctors of Calcutta were worried with the manner of this death (especially the mode of infection) and they voiced their suspicion in a letter to the director of the School of Tropical Medicine.

However, the police came into the picture much later. While many people associated with the family suspected foul play, they were reluctant to go to the police for fear of smearing the name of an aristocratic family. Finally, one family member submitted a petition to the deputy commissioner of police in Calcutta in January 1934, regarding the possible murder of Amarendra. ${ }^{1}$ Also, a complaint was lodged in the Tollygunge Police Station against Benoyendra Pandey and his associates. The subsequent investigations revealed the full extent of the murderous plan. The main investigation team was led by Le Brocq, a competent officer of the Calcutta police and Sarat Chandra Mitra of the Bengal Intelligence Service., ${ }^{1,4}$

\section{Modus Operandi}

The details, as given below, were revealed in court at the time of the trial.

Benoyendra Pandey used a man named Dr Tara Nath Bhattacharya. Later investigation revealed that he was not a trained doctor at all but pretended as such. But many newspapers at that time referred to him as "doctor" and because of his role in this murder scheme, some foreign newspapers even made the headline "allegations against Indian doctors" (The Straits Times, Singapore; 3 August 1934.) He was actually a research assistant in a laboratory of Calcutta Medical Supply Concern on Cornwallis Street. ${ }^{3}$ But through association and falsification, he had established himself as a doctor, interested in bacteriology and even used the false degree of Diploma in Tropical Medicine (DTM). Through his work as a laboratory assistant, he was familiar with the basic concepts of microbiology; so he could advise Benoyendra on how to use bacteria as a murder weapon. It turned out that this was not the first time that the duo had done so. Earlier, they had also tried to infect Amarendra with tetanus through an infected Pince-Nez, but the plot had failed. This Tara Nath had then tried to obtain strains of a virulent plague bacilli from Haffkine Institute, Bombay in May 1932 but the institute refused to supply this microbial strain without permission of competent authority (surgeon general of Bengal). This was the only place in India where live plague bacilli was available. Then, Tara Nath and Benoyendra thought of plan B. Tara Nath started working in the laboratory of one Dr Ukil of Calcutta with plague bacilli. For this work, he had obtained false letters of reference from one Dr Sivapada Bhattacharya of Calcutta. He declared that he had discovered a cure for plague and needed to test it against the bacteria. In this laboratory of Dr Ukil, he tried to subculture the bacilli to obtain sufficient sample for the murder, but failed.

Then he obtained a letter of introduction from Dr Ukil to Haffkine institute and went to Bombay. There, after some initial roadblocks, he managed to gain entry inside the Arthur Road
Infectious Diseases Hospital and persuaded Dr Patel there to supply him with a tube of live plague culture. ${ }^{4} \mathrm{He}$ started a sham laboratory experiment with the culture but after 5 days, once he was sure of the virulence of the bacilli, he suddenly left for Calcutta with the culture tubes without any explanation. Thus, they managed to get their biological murder weapon.

The next part of the plan was never revealed in details. Apparently, they got hold of an accomplice and trained him to inject the bacilli into Amarendra's arm in a busy station. This accomplice was never caught. Also, what happened to the rest of the culture sample is not known.

\section{Further Legal Proceedings ${ }^{B}$}

As Amarendra's death was the subject of police investigation, the medical evidence was again reviewed. Dr Santosh K Gupta of the school of tropical medicine, Calcutta examined the blood culture and reported "suspicious bipolar rods." He consulted with the professor of pathology, Captain Pasricha. The cultures were inoculated into a white rat, which died and postmortem examination of the rat revealed plague bacilli. Thus, the cause of death was established beyond reasonable doubt. The microbiological slides were submitted as evidence at the trial and the judges examined them under the microscope.

Meanwhile, investigation was ongoing to find the perpetrators of the crime. Although many people suspected Benoyendra, it was not easy to link him to the crime. The affairs at Bombay, as mentioned earlier, were revealed much later through efforts of the family lawyer.

Benoyendra had traveled to Bombay earlier in 1932 and under a false pretence, tried to obtain plague bacilli. But the Haffkine Institute turned him down. This information was revealed by the family attorney, Mr Kalidas Gupta with the help of a local guide in Mumbai named Ratan Salaria. Ratan was the all-purpose handyman for Benoyendra during his stay at Bombay. Kalidas Gupta was an astute lawyer, adept in digging up clues. It was he who also secretly met Balikabala, the mistress of Benoyendra and found out that Benoyendra often met Taranath at her home. The name of Taranath in conjunction with the theft of plague bacilli from Bombay was already known to the police. This was thus, the first proven connection of Benoyendra with this nefarious scheme.

During the court hearings, one Ashok Mitter came forward as witness. ${ }^{5}$ He was a student who knew Amarendra. He said that he was present at Howrah Station on the day of the incident. After the fatal pin-prick, he had examined Amarendra's arm and found a puncture mark along with a drop of liquid on his shirt sleeve. ${ }^{5}$

Benoyendra and his associates naturally pleaded not guilty in court. But the overwhelming evidence against them was enough to indict them without a shred of doubt. ${ }^{\mathrm{C}}$

Dr Sivapada Bhattacharya was also arrested in this case. He was a professor in the School of Tropical Medicine at that time. He was charged with helping the conspirators and also tampering

B As mentioned earlier, this case gained notoriety internationally. On February 25, 1935 the Time magazine published an article titled "Murder with germs" describing the incident. In this article, the murderer is named as "Benayendra Nath Pandey" although in the verdict of the Calcutta High Court, his name is Benoyendra Chandra Pandey.

c In 1950, this incident was recollected again in certain newspapers. In a distinct racist tone, the newspaper (The Straits Times, 11 May 1950, Page 10) wrote that "Calcutta can be terrible when its passions are excited." 
with evidence and making it disappear. He also visited Deoghar with Benoy when the first attempt to kill Amarendra with tetanus bacilli was made. He was also one of the attending doctors during the last hours of Amarendra and although this was a suspected case of plague, he did not inform the authorities. He was later acquitted.

The conspirators were sentenced to transportation to cellular jail, Andaman Islands, for life. But the actual murderer, the man who pricked Amarendra with the lethal needle at Howrah station, was never apprehended. While delivering the verdict, Justice LortWilliams commented that this case was "probably unique in the annals of crime." ${ }^{2}$ However, later similar uses of biological murder weapons were reported from other parts of the world.

Benoyendra Pandey was transported to the cellular jail but after the independence of India in 1947, he was freed as part of general amnesty when other political prisoners were released. But when he went back to Pakur, he showed signs of mental illness and started threatening his family members. The family members informed the police. But Benoyendra locked himself inside the haveli and refused to surrender. There was a gunfight with the police and Benoyendra was killed. The fate of Taranath Bhattacharya is largely unknown. Some accounts say that he went mad at prison.

\section{References}

1. Gauba KL. Famous trials for love and murder. Delhi: Orient Paperbacks; 1967.

2. Judgement Calcutta High Court. Benoyendra Chandra Pandey And anr. vs Emperor on 10 January, 1936. [Cited 2019 Sept 29]. [Internet]. Available online from https://indiankanoon.org/doc/ $1586771 \%$.

3. Sarkar S. Murder in the city: twelve incredible case files of the Kolkata Police. Kolkata: Speaking Tiger Publishing Private Limited; 2018.

4. Arnold D. Toxic histories: poison and pollution in modern India. Cambridge: Cambridge University Press; 2016.

5. Punctured Arm Mystery. The Straits Times. 2 May 1934. 